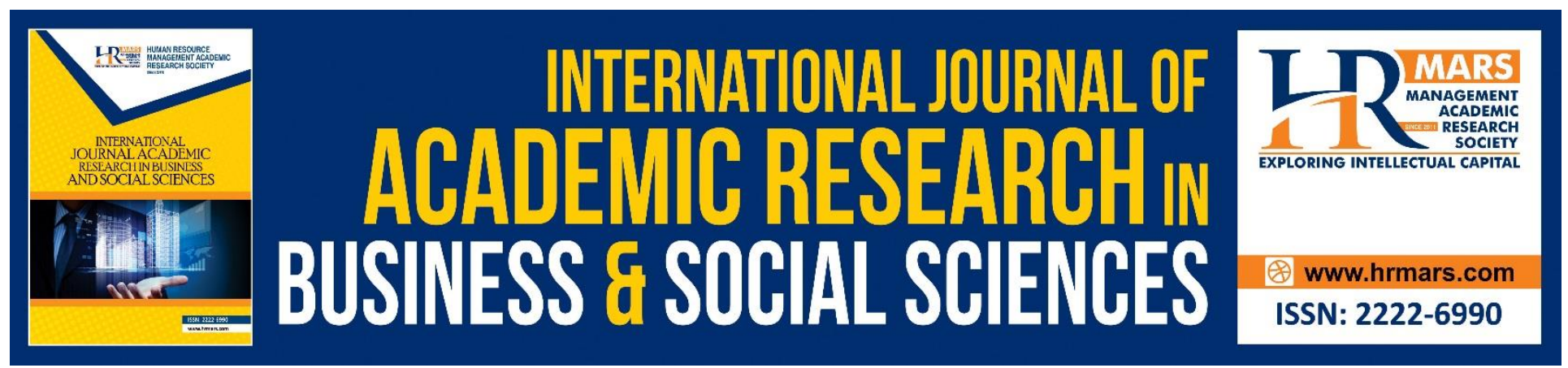

\title{
Social Entrepreneurship Aspiration: Enhancing the Social Entrepreneurial Interest among Malaysian University Students
}

Hariyaty Ab Wahid, Rafiduraida Abdul Rahman, Wan Salmuni Wan Mustaffa, Radin Siti Aishah Radin A. Rahman \& Norsamsinar Samsudin

To Link this Article: http://dx.doi.org/10.6007/IJARBSS/v9-i1/5518

DOI: $\quad 10.6007 /$ IJARBSS/v9-i1/5518

Received: 08 Dec 2018, Revised: 24 Jan 2019, Accepted: 06 Feb 2019

Published Online: 09 Feb 2019

In-Text Citation: (Wahid, Rahman, Mustaffa, Rahman, \& Samsudin, 2019)

To Cite this Article: Wahid, H. A., Rahman, R. A., Mustaffa, W. S. W., Rahman, R. S. A. R. A., \& Samsudin, N. (2019). Social Entrepreneurship Aspiration: Enhancing the Social Entrepreneurial Interest among Malaysian University Students. International Journal of Academic Research in Business and Social Sciences, 9(1), 11421154.

Copyright: (C) 2019 The Author(s)

Published by Human Resource Management Academic Research Society (www.hrmars.com)

This article is published under the Creative Commons Attribution (CC BY 4.0) license. Anyone may reproduce, distribute, translate and create derivative works of this article (for both commercial and non-commercial purposes), subject to full attribution to the original publication and authors. The full terms of this license may be seen at: http://creativecommons.org/licences/by/4.0/legalcode

Vol. 9, No. 1, 2019, Pg. 1142 - 1154

Full Terms \& Conditions of access and use can be found at http://hrmars.com/index.php/pages/detail/publication-ethics 


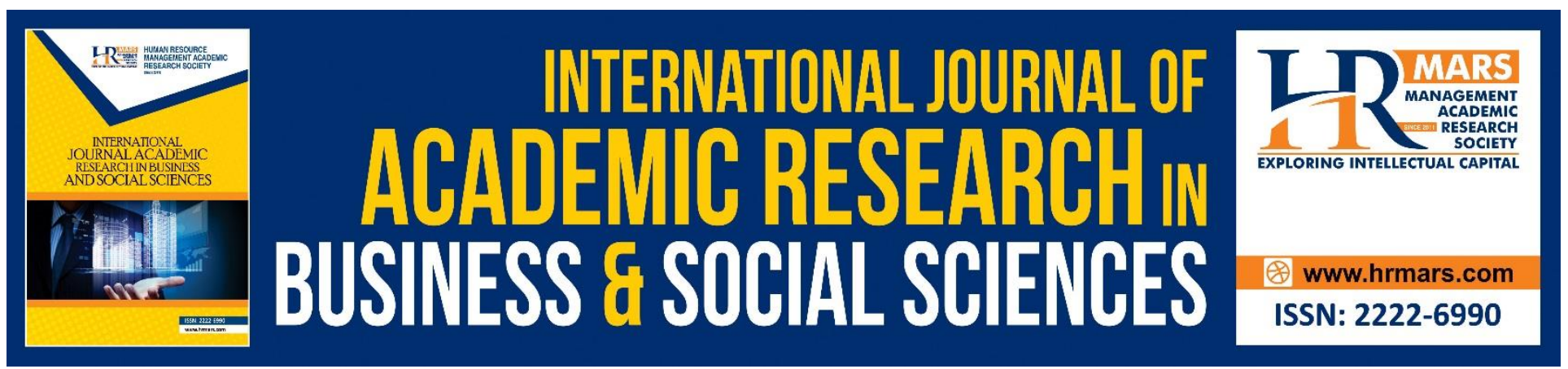

\title{
Social Entrepreneurship Aspiration: Enhancing the Social Entrepreneurial Interest among Malaysian University Students
}

\author{
Hariyaty Ab Wahid ${ }^{1}$, Rafiduraida Abdul Rahman², \\ Wan Salmuni Wan Mustaffa ${ }^{3}$, Radin Siti Aishah Radin A. Rahman ${ }^{4} \&$ \\ Norsamsinar Samsudin ${ }^{5}$ \\ 1,2,3,5 Universiti Pendidikan Sultan Idris, ${ }^{4}$ Universiti Kebangsaan Malaysia, Malaysia
}

\begin{abstract}
The concept of social entrepreneurship is increasingly popular throughout the world. In Malaysia, among the issues often being discussed is pertinent to the employability of its graduates in the job market and the reluctance of those graduates to kick-start any of entrepreneurship ventures. This issue needs to be wisely taken as university students will be the valuable human capital force for the country. At the same time, entrepreneurship should continue to be the starting point of the student's career with social entrepreneurship as one of the preferable option. Social entrepreneurship career aspiration need to be disseminated, introduced and cultured among students. Producing as many social entrepreneurs in the community could help to enhance the social status of the society, as well as encouraging rapid economic development of the country. University students in this country need to be exposed and inculcated with social entrepreneurial concepts and opportunities for them to mobilize social and economic development through their choice of careers. Hence, this conceptual paper aims to explain the aspirations of social entrepreneurship career with emphasis on both concept of social entrepreneurship and social entrepreneurs, social entrepreneurship aspiration and ways to enhance social entrepreneurship interest among Malaysian university students.
\end{abstract}

Keywords: Social Entrepreneurship, Career Aspiration, Malaysian University Student

\section{Introduction}

Students at various levels of study should be aware of their career choices, mainly those who are yet at the tertiary education. Basically, education institutions will expose the students with career awareness and necessary information regarding career options which are related to the students' field of studies. Unfortunately, there are still a number of students who are found to be less satisfied with the careers information and exposure they received at the university. They also complained that career services are more focused on students who want to apply for work in large organizations or 
corporate training schemes compared to students who wish to apply for jobs in small and medium enterprises or non-profit organizations (Higgins and Redman 2011). Moreover, the graduates feel that the university needs to introduce students with a diverse range of careers, since these last jobs with regular and full-time jobs may no longer be the dream of a few. There were graduates who want to be exposed to a more sustainable and challenging type of career as viable alternative as how to get self employed for instance. They are keen to know more on the functional role of a career that gives them autonomy, responsibility and diversity (Higgins, 2011) as opposed to 'feeding' by being subordinate without the opportunity to innovate. They also want challenging and interesting jobs, which enable them to apply skills, knowledge, critical and creative thinking about the work. In addition, they want to make changes in the organization and see how their job contributes to the success of the company which they work in, the customers that they serve for or local communities which also benefit from their work.

As suggested by Brown et al. (2010), if a country wants to continue to succeed in its future economy, it should take into account how graduates can contribute to the economy and create jobs that can add value to human life. The productive economy should be a result of social contribution rather than market competition or personal gain. Consequently, Higher Education Institutions (HEIs) need to build human capital that understand that their work should have social and moral dimensions. This effort is expected to create graduates who can challenge the inequality that exists and become more altruistic (McArthur, 2011).

Hence, an exposure to basic social entrepreneurial skills and social entrepreneurship endeavor should be given especially to those who are interested to stimulate their interest and desire to venture into social entrepreneurship. It's time to pass on to social entrepreneurship to fill the aspirations of a student's career that is increasingly seeking diversity and the opportunity to become an extraordinary human being who are capable of contributing towards remarkable community changes. Hopefully, the effort to create the positive perception, interests, attitudes and thought on social entrepreneurship as a career option can be mould, polished and guided accordingly among the students before they get graduated.

\section{Entrepreneurship and Social Entrepreneurs}

Social entrepreneurship is an entrepreneurial approach that is still at the infant stage and evolves in tandem with the entrepreneurial education itself though their related practices are reported to have been hundreds of years (Hariyaty et al. 2013; Radin Siti Aishah et al. 2016). The dynamic growth of human capital, economic and social transformation of a country often relate to entrepreneurial approaches and values. Herein, social entrepreneurship has been identified as one of the approaches that enormously contributing towards the economic, social and nature increase of a country (Bornstein and Davis 2010; Mohammad Reza et al., 2010; Sommerrock 2010; Suraini et al. 2016).

According to Alvord et al. (2002), social entrepreneurship is the merger of a business enterprise with social impact. Entrepreneurs will use their business skills and knowledge to create businesses that can accomplish social goals in addition to viable trade. Nonprofit organizations can create business 
subsidiaries and use them to generate profits or benefits that can be utilized for social purposes (Nicholls and Cho 2008). In addition, profit-based organizations can also engage in social entrepreneurship by donating some profits or organizing activities to achieve social goals. Such initiatives involve the use of resources generated from successful business activities to promote and sustain social activities (Verma 2009).

Tan et al. (2005) concludes that social entrepreneurs are individuals who meet the following five conditions; (i) to combine and use entrepreneurial skills to solve community problems, (ii) involve the whole or part of the community in the process, activity or project, (iii) activities, processes or projects undertaken in a timeframe, (iv) the process or project must be partially or wholly for the community, (v) to innovate and take risks. Obviously, what distinguishes social entrepreneurs from commercial entrepreneurs is their goals and operations. Social entrepreneurship is motivated by the aim to benefit the community and the operation is channeled to materialize it.

From the Islamic perspective, since the time of Prophet Muhammad; entrepreneurship has proven to be a strategic career and is a major source of economic development. Islam as a lifelong way of life, strongly encourages its people who are involved in entrepreneurship to have a characteristic and commendable nature by not merely thinking about financial gain as well as material for personal gain. In this regard, today's entrepreneurs, especially those who are Muslims, need to evaluate what they can contribute to the community and not pursuing profits only. The main goal should be focused on getting the blessings and pleasures of Allah SWT (Rohami, 2013). Muslim entrepreneurs are also encouraged to practice the concept of Ubudiyah which is the value and courtesy to avoid misconduct and always do good (Ab Mumin \& Suhaili, 2009). Muslim entrepreneurs are also required to serve to meet human needs and sincerely carry out responsibilities to the community. This is explained by a hadith which means:

"It was narrated from Salim from his father that Rasullullah said:" Every Muslim is a brother of another Muslims in which he cannot condemn him and neither surrender his brother to his enemy (kafir). Whoever fulfills the wishes of his brother, then Allah will release him from hardship in the Hereafter, and whoever hides the disgrace of his brother in the world then Allah will hide his disgrace too in the Hereafter. "

(Sunan al-Tarmizi, Kitab al-Hudud, Bab Ma jaa fi al-Sitr 'ala al-Muslim, no. Hadith 1346 in Ab Mumin Ab Ghani \& Suhaili Sarif,(2009: 7))

Among the important roles of social entrepreneurship towards community and the nation is its ability to eliminate extreme poverty and famine phenomena (Alvord et al., 2002; Mair and Marti, 2005; Bornstein, 2007; Mohammad Reza et al., 2010), championing community rights and universal foundation of education (Alvord et al., 2002; Mair and Marti, 2005; Bornstein, 2007), championing gender equality and at the same time empowering women (Mair and Marti, 2005; Bornstein, 2007) (Mair and Marti, 2005; Bornstein, 2007), improving maternal health care (Mair and Marti, 2005; Bornstein, 2007), fighting HIV / AIDS (Mair and Marti, 2005; Bornstein, 2007) and malaria and other 
INTERNATIONAL JOURNAL OF ACADEMIC RESEARCH IN BUSINESS AND SOCIAL SCIENCES

Vol. 9, No. 1, Jan, 2019, E-ISSN: 2222-6990 (C) 2019 HRMARS

diseases (Mair and Marti, 2005; Bornstein, 2007); and raise awareness on environmental preservation (Mair and Marti 2005; Verma 2009).

In addition to the community, social entrepreneurship is also able to provide opportunities for individual self-improvement (Sarimah Hanim and Abd. Rashid, 2008). From the perspective of human capital development, the quality that exists in social entrepreneurs should be emulated and cultured by university students. Social entrepreneurs are seen as individuals who always have innovative solutions to social problems faced by society (Hariyaty et al 2018). They are also individuals who stimulate economic increase by finding new way(s) or better way to perform thing. What is interesting about social entrepreneurs is that they are social entrepreneurial leaders of common people who make extraordinary things (La Barred and Fishman et al., 2001; Morse and Dudley, 2002).

Social entrepreneurs also have the same characteristics as traditional entrepreneurs in which they are skilled in making a transformation of business. Moreover, social entrepreneurs act as agents of change to their communities (Mair and Marti, 2005). A social entrepreneur will take on open opportunities, which are not realized by others, to improve the community system, inspire new approaches and also think of new ways of solving communities' problems. If an entrepreneur succeeds in opening a new business, a social entrepreneur will think of a new solution to a social problem and implement it to improve the state of the community (Hariyaty et al. 2016; Suraini et al. 2016).

In this regard, in order to help realizing the country's desire to create first-class human capital and to produce more graduates in the field of entrepreneurship and social entrepreneurship in particular, the HEls in the country has been urged to nurture the culture of social entrepreneurship (Norasmah and Hariyaty 2014). This is in line with the 'nature' of HEl itself as a systematic and formal organization of curriculum and administration aspects by offering academic programs to provide students with professional skills, self-esteem and high competitiveness (Rohaila, 2007) for the purpose of helping the country overcome the social and economic crisis. Directly, HEls are also contributing to economic and social innovation by developing knowledgeable and experience human capital (Ministry of Education, 2001).

\section{Social Entrepreneurship Aspiration}

Social entrepreneurship is a branch of entrepreneurship fields that provides potential primary or secondary career. The success of big names such as Professor Dr. Muhammad Yunus (Founder of Grahmeen Bank in Bangladesh), Pamela Hawley (Founder of UniversalGiving.com in the United States), Sulaiman Al- Rajhi ( Al Rajhi Bank), Tan Sri Syed Mokhtar Syah bin Syed Nor Al-Bukhary (Founder of Al-Bukhary Foundation in Malaysia), Dr. Maria Montessori (Founder of Montessori in Italy), Florence Nightingale (Modern Nurse at U.K.), Jean Monnet (pioneer of ECSC in France) as a part of prominent social entrepreneurship figures may be heard by public ( Mohd Adib and Mohamad Yazid 2015; Hariyaty 2014). They are social entrepreneurs who often been associated as social innovators in society although their contributions through social entrepreneurial endeavors have not been clearly understood by some (Noor Lela et al. 2016). Many still do not know what those social entrepreneurs have contributed to the community and what are the social entrepreneurial approach that has been 
identified and recognized to help transform the landscape. They also promote innovations to improve the performance of social enterprises (Changhwan 2018).

In Malaysia, social entrepreneurship career aspirations need to be sown and formed from the very beginning starting from the pre-school to elementary school. When the pupil begins to set foot in elementary school, the main focus should be made on introducing social entrepreneurship as one of the career option for their future. Teachers may frequently ask questions of what the pupils ideally want to be despite they may only respond by saying the typical type of work they know without taking into account their interests and abilities. Then, exposure to the social entrepreneurship career should be continued to the second level of education covering secondary schools and extending to the tertiary level with more effective methods and strategies. To materialize this aspirations, the trainee teacher's training should consider embedding this commitment and effort on cultivating social entrepreneurship as a career choice in the curriculum. Appropriate and adequate trainings must be carried out to initiate, groom and intensify the teacher's skills to successfully cater the aims.

At the university level, the effort must be put on the enculturation of social entrepreneurship. Typically, graduates who have studied subjects or areas such as accounting, legal, business or marketing management usually expect to get paid for vacancies in any of business firms; but the tendency to combine the career aspirations of graduates with their career motivation would be the risk of limiting their career choices. Herein, the university should remind graduates that they can choose to work anywhere as long as they know what they are doing and then become responsible and willing to make changes in society. This is because, a social entrepreneur is an ordinary individual who does extraordinary things in different environments or landscapes (Alvord et al. 2002). Adherence to the traditional career success, as the students being motivated and inspired to enhance their professional skills, they can also consider and apply social entrepreneurship attitudes, skills and practices to obtain advancement in the organization they work with.

In general social entrepreneurship and social enterprise in particular, the form of job opportunities that can be offered to graduates is the opportunity for graduates to work for nonprofit organizations in the pursuit of career in profession that is traditionally associated with business companies. Additionally, there are also opportunities to engage with businesses that can benefit the community rather than stakeholders. The career development opportunities available by social enterprises include the opportunity to work in a dynamic organization, having a clear business strategy and direction and meaningful direction, the opportunity to engage in initiating something that benefits the society, the benefits of working for small companies and simple, the opportunity to build niche sector, the opportunity to become innovative and develop new services for social/social purposes (Changwan 2018).

What questions can be asked about what entrepreneurship and social enterprise can offer to personal development, social and professionalism of graduates? So the answer is career opportunities and professional development. Courses and training provided by the university should expose students to social enterprise ideas at an earlier stage in career management affairs at universities to broaden their 
career path of choice and allow them to explore ideas that can bring more than just returns for life. However, students should be reminded that different employers (social enterprise operators) may offer different employment opportunities. Additionally, by creating and managing social enterprises in universities, students can develop their social entrepreneurial skills, collaborate with friends, and build an understanding that business processes such as financial and marketing management are also important in ensuring that governed social enterprises have a viable and empowered advanced. Proper training helps to catalyze the student's social entrepreneurship career aspirations.

However, the social entrepreneurship career should be differentiated with the career of a social worker so that there is no overlap in the understanding of the two. Career as a social entrepreneur or career as a social worker is both found to solve problems in society, but the approach used is different. A social worker is an individual engaged in a professional job in which the use of expertise is more important than altruism. Most social workers are involved with the rehabilitation works in social welfare sphere, handling and meddle with related charity activities/programs to help humans achieve effective social functionality (Samir \& Winny 2009). In contrast, the career of social entrepreneurs who combine entrepreneurial skills and altruism to solve social problems through innovation and risk taking in a period of time (Tan et al., 2005; Hariyaty et al., 2012).

\section{Enhancing the Social Entrepreneurial Interest among University Students}

Recently, students who are active in entrepreneurial activities at HEls not only want to fulfill the demand by offering something in the market and making profits solely. They are looking for social enterprising platform to make changes. So what steps can be taken by stakeholders to teach students to form a resilient and profitable social enterprise? What is the form of class, course or program as well as experience that needs to be offered and delivered? Some experts in entrepreneurship have come up with eight methods that can be practiced in entrepreneurial offerings as one of the key components in the business school curriculum.

i) Utilize student's social entrepreneurial interest

Students need to be encouraged to start their own social business in the first classroom of entrepreneurship until they get out of campus and enter the workforce. They need to start making a meaningful career choice from the beginning of the study. In fact, some entrepreneurs say that age is not a measure of success in entrepreneurship. Students may begin to engage in social entrepreneurship as soon as they learn the skills related to social entrepreneurship and be able to identify good opportunities to start their social enterprise. Therefore, students who are interested in the entrepreneurial career should be identified and they should continue to be encouraged and supportive to continue to develop their career in the field. Here, the collaboration between academic staffs, faculty and social enterprise management is important to leverage on student's interest in social entrepreneurship. Continued incentives should be channeled to the students so that interest in social entrepreneurship career will not vanish.

ii) Implementing social entrepreneurship through coursework 
When students and faculty offering entrepreneurship-related programs are increasingly committed to their entrepreneurial programs and activities, directly and indirectly related topics of social entrepreneurship can and are believed to be integrated across the curriculum. Social entrepreneurship can be taught in general to all HEls' students through coursework or practicum involving entrepreneurial skills for the benefit of society. The topics and case related to social entrepreneurship can be integrated into the mainstream curriculum.

iii) Teaching social entrepreneurship across disciplines

Entrepreneurship has now been introduced and taught across campuses, such as engineering campuses, journalism, nursing, fashion designs and so on. In this regard, social entrepreneurship needs to be introduced and taught across disciplines as well so that students can leverage their knowledge and skills associated with them to start working themselves with the soul and mind of social entrepreneurs. Social entrepreneurship is not just a social business field but it is a thought that includes a set of skills that can be applied to any discipline. Business and entrepreneurship faculties may also reflect on methods and mechanisms of collaboration with non-business faculties to build early ideas on how to integrate and teach social entrepreneurship across disciplines.

iv) Offer more social entrepreneurship role models

Most business programs expose their students to the success of executives and business owners. Along with that, faculty or school that focuses on general entrepreneurship and social entrepreneurship in particular, should also bring the concept to a more special way of engaging an authentic entrepreneur into the academic setting notwithstanding. The best way to engage students with entrepreneurship is to bring in successful entrepreneurs to the campus to share their entrepreneurial success experience. The same must also be applied to inculcate social entrepreneurship. Students should be given the opportunity to meet and get acquainted with local social entrepreneurs, by face-to-face and not only learn their success through case study, exam papers and slideshows only in the classroom. Real role model engagement in the curriculum is hoped to inject social entrepreneurial spirit into students by sharing their favorite joy sand sorrows as well as their achievements in entrepreneurship. Furthermore, students can also have the opportunity to meet local social entrepreneurs through a visit to a company led by successful entrepreneurs and learn what makes entrepreneurs successful and what they have contributed to the community. By bringing in and engaging real entrepreneurs into entrepreneurial teaching and learning sessions at university, students will better understand entrepreneurship in general and social entrepreneurship specifically and at the same time likely to reinforce the aspirations of social entrepreneurship within themselves.

v) Engage students with out-of-classroom activities

Students can also be involved with out-of-classroom activities such as attending social entrepreneurship seminars, symposium or entrepreneurship career carnival. These activities can stimulate them to contribute to the change in society. They should also be given the opportunity to engage in various entrepreneur-related activities including service based learning or consulting activities by placing them at firms or business premises. They can also directly hear the owner's experience of the premises through this method, hold a face-to-face discussion with him and work 
with the successful ones. Innovation can also be learned by hands on through out-of-classroom activities like this.

vi) Offer real-world social entrepreneurial and Corporate Social Entrepreneurship (CSR) experience Education experience will be more authentic and wealthy when students can learn through their own actions and it is very practical in teaching and learning entrepreneurship. With sufficient funds, students may be able to visit the vibrant area or environment with real entrepreneurial activities and write social entrepreneurship-related cases based on what they observe and learn there. They can also be divided into groups and assisted in establishing real social businesses and running them. Focus should be given to business strategy, resources and product manufacturing, sales, lending methods and use of financial funds to help the community.

vii) Provide students with a wide range of social entrepreneurship career options Graduates with deep interest in social entrepreneurial career are no longer needed to search for jobs with other organizations. They are not only engage in social entrepreneurship career but also offer consulting services or consultants to companies or other business organizations with their knowledge, skills and experience and qualifications to help them execute their CSR activities. They can start as an internal social entrepreneur who serves other organizations, but still continue to contribute ideas to solve community problems through the platform of the organizations they join. At least they are able to propose innovative ideas to their employers regarding the CSR projects that the employer wants to implement.

viii) Enhancing social entrepreneurship programs to achieve their goals

When a faculty or business school claims that they are committed to social entrepreneurship, it must be ensured that the university's curriculum and operations are really reflexes against what is being said. It should enhance the social entrepreneurship program offered by always purifying and improving the program's filling with effective delivery methods. Evaluation of the effectiveness of every social entrepreneurial program offered must be made to ensure that the objectives are wellsuited. Social entrepreneurship programs need to be given due consideration to be used as a credited course in the faculty.

\section{Conclusion}

In line with the goals of the country that are actively trying to change the state of society from a government-dependent society to a self-sustaining and viable entrepreneurial society, the government has acted wisely by channeling incentives and actively promoting the community to be independent without expecting others to support the economy of oneself and the family. The increase number of entrepreneurs who involved in the field of entrepreneurship generally and social entrepreneurship specifically; can open up and offer more job opportunities to Malaysians. Little by little, 'wage-earner' cultures will be diminished and eradicated in society as well as enabling the existence of social entrepreneurs amongst quality graduates in the job market. Thus, in order to form a social entrepreneurial career among HEls students in this country, the driving force and attraction to entrepreneurship career must be identified and enhanced. Students as the state's assets that will 
color the world of employment should somehow be exposed to adequate and appropriate social entrepreneurship career aspirations so that they can choose the field after graduation as well as not merely expecting to be paid a mere wage. The aspiration of social entrepreneurship career is possible through education, by providing appropriate curriculum and co-curriculum as well as effective teaching (teaching and learning) methods. It is hoped that the explanation of social entrepreneurship career aspirations through this conceptual paper will open more in-depth discussion pertinent to enhancing the social entrepreneurship interest among HEls' students in this country.

\section{References}

Ab Ghani, A. M. \& Sarif, S. (2009). Keusahawanan Islam: Pembudayaan Di Kalangan Masyarakat Islam. In. Kamri, N., Mohd Balwi, M. A. W. F. \& Che Abdullah, A. F. (Eds.) Keusahawanan Islam, Konsep dan Isu-isu Pelaksanaannya (ms: 1-18). UM, KL: Jabatan Syariah dan Pengurusan.

Ab Wahid, H., Othman, N. \& Hussein, H. (2012). Keusahawanan sosial dan hubungannya dengan daya tahan terhadap tekanan dalam kalangan pelajar program Student in Free Enterprise (SIFE). in Khoo Yin Yin et al. (Eds). Korpus. Tanjong Malim: Penerbit UPSI.

Ab Wahid, H., Othman, N. \& Mohd Salleh, S. (2013). Social entrepreneurship contributions on the competitiveness of active students in the Students in Free Enterprise Program (SIFE) Malaysia. Proceedings of 6th International Seminar on Regional Education UKM-UNRI2013, pp.1919-1929.

Ab Wahid, H., Othman, N. \& Mansor, M. (2011). Meningkatkan daya tahan modal insan: pendekatan keusahawanan sosial. Kertas Kerja International Management Conference 2011. Anjuran Universiti Sultan Zainal Abidin, Kuala Terengganu, Terengganu, 16-17 April, pp. 201-213.

Ab Wahid, H., Ahmad, N, L., Othman, N. \& Wan Mustaffa, W. S. (2016). Kesosialan, Inovasi dan Orientasi Pasaran dalam Kalangan Pelajar Aktif Keusahawanan Sosial di Universiti Awam Malaysia, Journal of Global Business and Social Entrepreneurship (GBSE,) 1(2): 1-9.

Ab Wahid, H., Wan Mustaffa, W.S., Abdul Rahman, R. \& Salleh Hudin, N. (2018). Measurement Model Of Sociality, Innovation And Market Orientation Using Confirmatory Factor Analysis In Social Entrepreneurship Context. International Journal of Academic Research in Business and Social Sciences, 8(11): 76-96.

Abd Muin, M. A \& Isa, M.Y. (2015). Pernan Usahawan Berjaya dalam Keusahawanan Sosial Islam: Satu Penyelesaian Kepada Masalah Ekonomi dan Sosial, in Ibrahim, M.F. (Eds). Amalan Keusahawanan Islam: Konsep dan Isu Pelaksanaan. Kuala Lumpur: Pusat Pungutan Zakat, MAIWP.

Ahmad, N.L., Mohd Rhouse, S. \& Ab Wahid,H. (2016). Integrasi Nilai dan etika dalam Pendidikan Perakaunan ke arah Membentuk Usahawan Sosial dalam Kalangan Pelajar Perakaunan. Social Entrepreneurship and Community Engagement: Transforming Societies. Institut Sosial Malaysia: Kuala Lumpur. 
INTERNATIONAL JOURNAL OF ACADEMIC RESEARCH IN BUSINESS AND SOCIAL SCIENCES

Vol. 9, No. 1, Jan, 2019, E-ISSN: 2222-6990 ㄷ 2019 HRMARS

Alvord, S. H., Brown, L. D. , Letts, C. W. (2002). Social Entrepreneurship and Social Transformation: An Exploratory Study. Working Paper 15, Cambridge.

Aman Shah, S.H. \& Mohd Ali, A. R. (2008). Entrepreneurship. Shah Alam: Oxford Fajar Sdn. Bhd.

Bornstein, D. (2007). How to Change the World: Social Entrepreneurs and The Power of New Ideas. USA: Oxford University Press.

Bornstein, D. \& Davis, S. (2010). Social Entrepreneurship: What Everyone Needs to Know. USA: Oxford University Press.

Brooks, A. C. (2009). Social Entrepreneurship: A Modern Approach to Social Value Creation. New Jersey: Prentice Hall.

Brown, P., Lauder, H. and Ashton, D. (2010). The Global Auction: The Broken Promises of Education, Jobs, and Incomes. New York: Oxford University Press.

Changhwan Shin. (2018). How social entrepreneurs affect performance of social enterprises is Korea: The mediating effect of innovativeness. Sustainability 10(2643): 1-14.

Christie, F. (2008). Career pathways for graduates into the voluntary/community sector. Manchester: HECSU.

Gatchalian, M.L. (2010). An in-depth analysis of the entrepreneurship education in the Phillippines: an initiative towards the development of a framework for a professional teaching competency program for entrepreneurship educators. The International Journal of Research and Review 5: 51-73.

Haase, H. \& Lautenschläger, A. (2011). A Career Choice Motivations of University Students. International Journal of Business Administration 2(1): 1 - 13.

HEls Entrepreneurship Development Policy. (2010). Kementerian Pengajian Tinggi Malaysia. http://www.portal.mohe.gov.my/portal/page/portal/ExtPortal/MOHE MAIN_PAGE/NEWSEVENTS/p ublication/dasar pbgn keusahawanan ipt.pdf. [21 September 2018].

Higgins, H. (2011). Real Prospects 2011: Employers. Manchester: Graduate Prospects.

Higgins, H. \& Redman, J. (2011). Real Prospects 2011: Universities. Manchester: Graduate Prospects.

Hunt, I., Hennessy, M., O’Brien, E. \& Sherry, R. (2007). The graduate and the SME, Education, Knowledge \& Economy, 1:2, 199-210. 
INTERNATIONAL JOURNAL OF ACADEMIC RESEARCH IN BUSINESS AND SOCIAL SCIENCES

Vol. 9, No. 1, Jan, 2019, E-ISSN: 2222-6990 ㄷ 2019 HRMARS

Ishak, S. \& Che Omar, A.R. (2015). Keusahawanan sosial sebagai satu pendekatan inovatif ke arah transformasi sosial masyarakat: Kajian kes di Malaysia. GEOGRAFIA OnlineTM Malaysian Journal of Society and Space, 11 (8): 38 - 51.

Litzky, B.E., Godshalk, V.M. \& Walton-Bongers, C. (2010). Social entrepreneurship and community leadership: a service-learning model for management education. Journal of Management Education 34(1): 142-162.

Malecki, E.J. (2007). Geographical environment for entrepreneurship. IECER 2007, Montpellier. Ohio State University.

McArthur, J. (2011). Reconsidering the social and economic purposes of higher education, Higher Education Research and Development, 30:6, 737-749.

Ministry of Higher Education. (2016). Pelan Tindakan Keusahawanan IPT 2016-2020. (diakses pada 10 Februari 2017) http://www.mohe.gov.my/index.php/fokus/231-pelan-tindakan-keusahawanan-ipt2016-2020.

Mohd. Hamzah, M.I., Long,J., Abdullah, K., Mahbar, Z., Yamat, H., Ismail, Z., Abdul Wahab, J.L., Maidin \& N.F., Alias, R. (2011). Analisis Keperluan Majikan Terhadap Kemahiran Generik bagi Pembangunan Modal Insan, in Mahmood,Z., Abdul Wahab, J.L. \& Ibrahim, M.S. (Eds). Transformasi dan Inovasi dalam Penyelidikan. Bangi: Penerbit UKM.

Mohd Rhouse, S., Ahmad, N.L., Ab Wahid, H. \& Yeop Yunus, N. K. (2016). Social enterprising values among women entrepreneurs in Social Entrepreneurship and Community Engagement: Transforming Societies. Institut Sosial Malaysia: Kuala Lumpur.

Muhazzab Amin, S. \& Abdul, W. (2009). Pengantar Kerja Sosial. Kuala Lumpur: Utusan Publications \& Distributors.

Nasrudin, N. \& Harun, H. (2010). Aspirasi kerjaya keusahawanan dalam kalangan pelajar institusi pengajian tinggi awam. Jurnal Pendidikan Malaysia, 35 (1): 11-17.

Nicholls, A. \& Cho, A.H. (2008). Social entrepreneurship: the structuration of a field. In. Nicholls, A (Eds). 2008. Social Entrepreneurship: New Models of Sustainable Social Change. New York: Oxford University Press.

Niemiec, C. P., Ryan, R. M. \& Deci, E. L. (2009). 'The path taken: Consequences of attaining intrinsic and extrinsic aspirations in post-college life' in Journal of Research in Personality, 43, 291 - 306.

Noruzi, M.R., Westover, J.H., \& Rahimi, G. R. (2010). An exploration of social entrepreneurship in the entrepreneurship era. Asian Social Science, 6(6): 3-10. 
Perrini, F. \& Vurro, C. (2010). Developing an Interactive Model of Social Entrepreneurship. In. Hockerts, K., Mair, J. \& Jeffrey Robinson (Ed). Values and Opportunities in Social Entrepreneurship, hlm. 165180. New York: Palgrave MacMillan.

Radin A. Rahman, R.S.A., Othman, N., Lope Pihie, Z. A., Ab. Wahid, H. (2016). Entrepreneurial Intention and Social Entrepreneurship among Students in Malaysian Higher Education. World Academy of Science, Engineering and Technology International Journal of Social, Behavioral, Educational, Economic, Business and Industrial Engineering, 10(1): 175-181.

Sommerrock, K. (2010). Social Entrepreneurship Business Models: Incentive Strategies to Catalyze Public Goods Provision. UK: Palgrave Macmillan.

Stevenson, J. and Clegg, S. (2011). Possible selves: students orientating themselves towards the future through extracurricular activity, British Educational Research Journal, 37:2, 231-246.

Tan, W- L., William, J. \& Tan, T-M. (2005). Defining the 'social' in 'social entrepreneurship': altruism and entrepreneurship. International Entrepreneurship and Management Journal (1): 353-365.

Tomlinson, M. (2008). The degree is not enough: students' perceptions of the role of higher education credentials for graduate work and employability, British Journal of Sociology of Education, 29:1, 4961.

Verma, A. (2009). Social Entrepreneurship Management- A New Look at the People and the Potential. New Delhi: Global India Publications Pvt Ltd.

Weerawardena, J. \& Mort, G.S. (2006). Investigating social entrepreneurship: a multidimensional model. Journal of World Business 41: 21-35.

Yusof, R. (2007). Keberkesanan strategi pembelajaran pengalaman berasaskan model KOLB terhadap pembangunan kompetensi pelajar perakaunan di IPTA. Tesis Dr. Fal, Fakulti Pendidikan, Universiti Kebangsaan Malaysia.

\section{Acknowledgements}

This research is funded by Universiti Pendidikan Sultan Idris Research Grant (2017-0254-107-01).

\section{Corresponding Author}

Dr. Hariyaty Ab Wahid

Department of Business Management and Economics,

Faculty of Business and Management

Universiti Pendidikan Sultan Idris, 35900 Tanjong Malim, Malaysia.

Email: hariyaty@fpe.upsi.edu.my 